\title{
HISTOGRAM SCORE CONTRIBUTES FOR RELIABILITY OF DNA CONTENT ESTIMATIVES IN Brachiaria spp.
}

\author{
Notas do histograma contribuem para a confiabilidade das estimativas \\ do conteúdo de DNA de Brachiaria spp.
}

\author{
Ana Luiza de Oliveira Timbón, Roselaine Cristina Pereira², Vanderley Borges dos Santos ${ }^{3}$, \\ Fausto Souza Sobrinho ${ }^{4}$, Lisete Chamma Davide ${ }^{5}$
}

\begin{abstract}
Flow cytometry allows to estimate the DNA content of a large number of plants quickly. However, inadequate protocols can compromise the reliability of these estimates leading to variations in the values of DNA content the same species. The objective of this study was to propose an efficient protocol to estimate the DNA content of Brachiaria spp. genotypes with different ploidy levels using flow cytometry. We evaluated four genotypes (B. ruziziensis diploid and artificially tetraploidized; a tetraploid $B$. brizantha and a natural triploid hybrid), three buffer solutions (MgSO4, Galbraith and Tris- $\mathrm{HCl}$ ) and three species as internal reference standards (Raphanus sativus, Solanum lycopersicum e Pisum sativum). The variables measured were: histogram score (15), coefficient of variation and estimation of DNA content. The best combination for the analysis of Brachiaria spp. DNA content was the use of $\mathrm{MgSO} 4$ buffer with $R$. sativus as a internal reference standard. Genome sizes expressed in picograms of DNA are presented for all genotypes and the importance of the histogram score on the results reliability of DNA content analyses were discussed.
\end{abstract}

Index terms: Brachiaria ruziziensis, Brachiaria brizantha, colchicine, nuclear DNA content.

\section{RESUMO}

A citometria de fluxo permite estimar o conteúdo de DNA de um grande número de plantas rapidamente. No entanto, protocolos inadequados podem comprometer a confiabilidade dessas estimativas, levando a variações nos valores de conteúdo de DNA para uma mesma espécie. Neste trabalho, objetivou-se propor um protocolo eficiente para a estimativa do conteúdo de DNA de genótipos de Brachiaria spp. com diferentes níveis de ploidia, utilizando a citometria de fluxo. Foram avaliados quatro genótipos (B. ruziziensis, diploide e tetraploidizada artificialmente; B. brizantha tetraploide e um híbrido natural triploide), 3 soluções tampões $\left(\mathrm{MgSO}_{4}\right.$, Galbraith e Tris-HCl) e três espécies como padrões de referência interno (Raphanus sativus, Solanum lycopersicum e Pisum sativum). As variáveis mensuradas foram: nota do histograma (1 a 5), coeficiente de variação e estimativa do conteúdo de DNA. A melhor combinação para as análises do conteúdo de DNA de Brachiaria spp. por citometria de fluxo foi o emprego do tampão $\mathrm{MgSO}_{4}$ com o rabanete como padrão de referência. O tamanho dos genomas expresso em picogramas de DNA foi apresentado para todos os genótipos e a importância da pontuação do histograma na confiabilidade dos resultados das análises do conteúdo de DNA foi discutida.

Termos para indexação: Brachiaria ruziziensis, Brachiaria brizantha, colchicina, conteúdo de DNA nuclear.

(Received in august 23, 2012 and approved in october 5, 2012)

\section{INTRODUCTION}

Brachiaria is used for feeding beef cattle, and is also widely used for milk production in Brazil. In 2006, species from the Brachiaria genus represented $85 \%$ of the 120 million hectares of cultivated Brazilian pastures (MACEDO, 2006).

The most cultivated species in Brazil are $B$. decumbens, B. brizantha, B. humidicola and B. ruziziensis, all of which present limitations such as being susceptible to leafhoppers or low tolerance to acidic, badly drained and poor soil. Thus, the combination of new characteristics of agronomic interest in new cultivar by means of selecting natural populations and attaining hybrids and inter-specific (MILES et al., 2004; PEREIRA et al., 2005) and intra-specific types (SOUZA SOBRINHO, personal communication). However, with exception of $B$. ruziziensis, which is a sexual diploid, the others are tetraploids and present apomixis reproduction, which

\footnotetext{
1Universidade Federal de Lavras/UFLA - Departamento de Agricultura/DAG - Lavras - MG - Brasil

2Universidade Federal de Lavras/UFLA - Departamento de Biologia/DBI - Lavras - MG - Brasil

${ }^{3}$ Universidade Federal do Acre/UFAC - Departamento de Ciências Agrárias - Rio Branco - AC - Brasil

${ }^{4}$ Empresa Brasileira de Pesquisa Agropecuária/EMBRAPA - Embrapa Gado de Leite - Centro Nacional de Pesquisa de Gado de Leite - Juiz de Fora MG - Brasil

${ }^{5}$ Universidade Federal de Lavras/UFLA - Departamento de Biologia/DBI - Lavras - MG - Brasil - lisete.ufla@gmail.com
} 
leads to the necessity of polyploidy induction for the accomplishment of inter-specific crossings. The certification of the resultant plants whether by interspecific crossings, chromosomal duplication, from collections in pastures or in improved populations in open field can be carried out by flow cytometry.

As flow cytometry is a relatively simple and fast analysis, it can assist in the identification of the genotypes through the determination of the DNA content, making possible the evaluation of a large number of plants. However, for the same species, it is common to see the occurrence of variation in the estimate of the nuclear DNA content obtained by flow cytometry (RAYBURN et al., 1989; MICHAELSON et al., 1991; GREILHUBER, 1998; SUDA; KYNCL; FREIOVA, 2003; RAYBURN et al., 2004; GREILHUBER, 2005). This variation in the amount of DNA can be explained by instrumental or methodology errors, interference of the cytosolic components with the DNA stain, differences between laboratories and taxonomic heterogeneity of the material in study (DOLEŽEL; GREILHUBER; SUDA, 2007). Furthermore the same authors report that the main factors that intervene with the preparation of the samples are: buffer extraction, standard of reference and fluorochromes. With regard to fluorochromes for the estimate of DNA content, indications are made for those that mark all the nitrogenous bases indistinctly, as is the case of the propidium iodide, ethidium bromide and SYBR green.

As with comparison of the efficiency of nuclei isolation buffer, there are few citations in literature (LOUREIRO et al., 2006). The buffer helps in the release and maintenance of the integrity of the nuclei and facilitates the coloration of the DNA. A universal buffer that efficiently functions for all the types of tissues and or vegetal species does not exist, which makes previous studies necessary to identify the buffer most adequate for each species.

In studies with Brachiaria, Penteado et al. (2000) and Pinheiro et al. (2000) using the buffer Galbraith (GALBRAITH et al., 1983) with modifications and Ishigaki et al. (2010) considered the use of another buffer containing Tris- $\mathrm{HCl}$ for the identification of duplicate genotypes of Brachiaria ruziziensis. These examples motivate the evaluation of different buffers to contribute for higher experimental precision in Brachiaria spp.

With regard to the choice of the reference standard, this must be carefully assessed to guarantee the estimates obtained (PRICE; JOHNSTON, 1996; JOHNSTON et al., 1999). The reference standard is a plant or animal species whose DNA content was previously established, allowing the estimation of the DNA content of any sample for comparison (DOLEŽEL; GREILHUBER; SUDA, 2007).

Buffer extractions and reference standards, as well as the target species intervene with the coefficient of variation values $(\mathrm{CV}=$ ratio of the standard deviation) (DOLEŽEL et al., 1989; LOUREIRO et al., 2006), which indicates the quality of the nuclear suspension (SHAPIRO, 2003; DOLEŽEL; BARTOS, 2005). The CV expresses the width of the G1 peaks (sample and reference standard) formed in the histogram and indicate the trustworthiness of the results. Thus, CVs with values between 1-2\% are considered of high quality and, next to $3 \%$, as routine results (MARIE; BROWN, 1993). In international publications, coefficients of variation lower than 5\% are acceptable (GALBRAITH et al., 1983). According to Ulrich and Ulrich (1991), to have a high resolution analysis, the histogram must contain coefficient of variation with peaks below $1.5 \%$.

Considering the variation in the results obtained by different authors, this work aims to establish an efficient protocol to estimate the DNA content using a score of the histogram generated by flow cytometer to verify the influence of extraction buffers and reference standards in the trustworthiness of the DNA content estimates to taxa of Brachiaria with different ploidy levels.

\section{MATERIALS AND METHODS}

Four genotypes of Brachiaria with a preestablished number of somatic chromosomes were evaluated: diploid $B$. ruziziensis $(2 \mathrm{n}=2 \mathrm{x}=18)$; artificially tetraploidized B. ruziziensis $(2 \mathrm{n}=4 \mathrm{x}=36)$; a natural triploid hybrid $(2 \mathrm{n}=3 \mathrm{x}=27)$ and a commercial cultivar tetraploid of B. brizantha - Marandu $(2 \mathrm{n}=4 \mathrm{x}=36)$.

Three internal reference standards calibrated by Doležel, et al. (1989) and Doležel et al. (1992) were used, as seen in table 1. Seeds of these three species had been donated by Prof. Dr. Jaroslav Doležel, from the Laboratory of Molecular Cytogenetics and Cytometry, Institute of Experimental Botany, Sokolovská, Czech Republic.

In the preparation of each sample, we used approximately between 20 to $30 \mathrm{mg}$ of apical young leaf tissue, completely expanded, with the same amount of foliar tissue from the internal reference standard. The leaves had been triturated in one of the three nuclei isolation buffers $\left(\mathrm{MgSO}_{4}\right.$, Galbraith and Tris- $\left.\mathrm{HCl}\right)$ whose compositions can be seen in table 2 . The nuclei suspension was stained with $25 \mu \mathrm{L}$ of a solution composed of propidium iodide $(1 \mathrm{mg} / \mathrm{mL})$ and $25 \mu \mathrm{L}$ RNAse. 
Table 1 - DNA content of reference standards used.

\begin{tabular}{llcl}
\hline & \multicolumn{1}{c}{ Description } & Content of DNA(pg) & Reference \\
\hline 1 & Raphanus sativus cv. Saxa & 1.11 & Doležel et al. (1992) \\
2 & Solanum lycopersicum cv. Stupické & 1.96 & Doležel et al. (1992) \\
3 & Pisum sativum cv. Ctirad & 9.09 & Doležel et al. (1989) \\
\hline
\end{tabular}

Table 2 - Composition of the three nuclei isolation buffers used for the analysis of flow cytometry in Brachiaria spp.

\begin{tabular}{|c|c|c|c|}
\hline & Buffer & Composition & Reference \\
\hline 1 & $\mathrm{MgSO}_{4}$ & $\begin{array}{l}9.53 \mathrm{mM} \mathrm{MgSO} \\
\text { mM } .7 \mathrm{H}_{2} \mathrm{O}, 47.6 \mathrm{mM} \mathrm{KCl}, 4.77 \mathrm{mM} \text { HEPES, } 6.48 \\
\text { DTT, } 0.25 \% \text { Triton X-100, } \mathrm{pH} 8.0\end{array}$ & Arumuganathan; Earle (1991) \\
\hline 2 & Galbraith & $\begin{array}{l}45 \mathrm{mM} \mathrm{MgCl}{ }_{2}, 30 \mathrm{mM} \mathrm{Na}_{3} \mathrm{C}_{6} \mathrm{H}_{5} \mathrm{O}_{7}, 20 \mathrm{mM} \text { MOPS, } 0.1 \%(\mathrm{v} / \mathrm{v}) \\
\text { Triton X-100, pH } 7.0\end{array}$ & Galbraith et al. (1983) \\
\hline 3 & $\begin{array}{l}\text { Tris- } \\
\mathrm{HCl}^{*}\end{array}$ & $\begin{array}{l}50 \mathrm{mM} \text { Tris-HCl, } 0.5 \% \text { PVP, } 0.01 \% \text { Triton }-\mathrm{X}, 0.63 \% \mathrm{Na}_{2} \mathrm{SO}_{4} \text {, } \\
\mathrm{pH} 7.5\end{array}$ & Ishigaki et al. (2010) \\
\hline
\end{tabular}

DTT - Dithiothreitol; HEPES- (4-(2-hydroxyethyl)-1-piperazineethanesulfonic acid ); MOPS = 3-(N-morpholino) propanesulfonic acid; Tris $=$ (hydroxymethyl) aminomethane and PVP $=$ polivinilpirrolidona.

For each sample we analyzed at least 10 thousand nuclei and used the logarithmic scale to measure fluorescence emission. The analyses were carried out through FacsCalibur flow cytometry (BD Biosciences, San Jose, CA, the USA). The histograms were generated by the program Cell Quest (Becton Dickinson and Company, San Jose, CA, the USA) and analyzed by the program WinMDI 2.8 (TROTTER, 2000).

In the histogram the axle $(\mathrm{x})$ represents the intensity of fluorescence of the marked nuclear DNA with Propidium iodide and, the axle (y), the number of events, that is, the number of analyzed nuclei.

For each sample, a histogram was generated and three variables were measured: a) the histogram score; b) variation coefficient and c) estimate of the DNA content.

For each histogram a score from 1 to 5 was given, as seen in figure 1 . The higher score of the histogram corresponds to the higher definition of the G1 peaks of the sample and the reference standard, as well as the lower amount of sub G1 particles, which are generated due to disruption of the nuclei which may compromise the trustworthiness of the estimates.

The coefficient of variation (average $\mathrm{CV}=$ standard deviation/average of nuclei in the G1 peak) was surveyed for each sample for the analysis of the histogram in the program WinMDI 2,8 (TROTTER, 2000). This coefficient of variation is represented in the histogram by the width, in the G1 peak medium position of the analyzed plant. Thus, the lower the width of the G1 peak, the lower the CV and the results obtained from these data will be more precise.

The amounts of nuclear DNA (pg) of the samples had been estimated by the equation: , where:

DNA sample $=\left(\frac{\text { G1 sample }}{\text { G1standard }}\right)$ x DNA standard, where:

DNA sample = amount of nuclear DNA of the sample (pg); G1 sample = position of the G1 peak of the sample; G1 standard = position of the G1 peak of the species reference standard used; DNA standard = content of DNA of the species reference standard used.

For the statistics analysis, we used a completely randomized block design $4 \times 3 \times 3$ (four genotypes, three buffers and three standards) with three repetitions. The averages were compared by the Scott-Knott test (1974) $5 \%$ of probability. The analyses were carried out with the use of the software SISVAR (FERREIRA, 2003; 2011). Spearmam's rank Correlation was carried out with the use of the program Genes (CRUZ, 2006). 


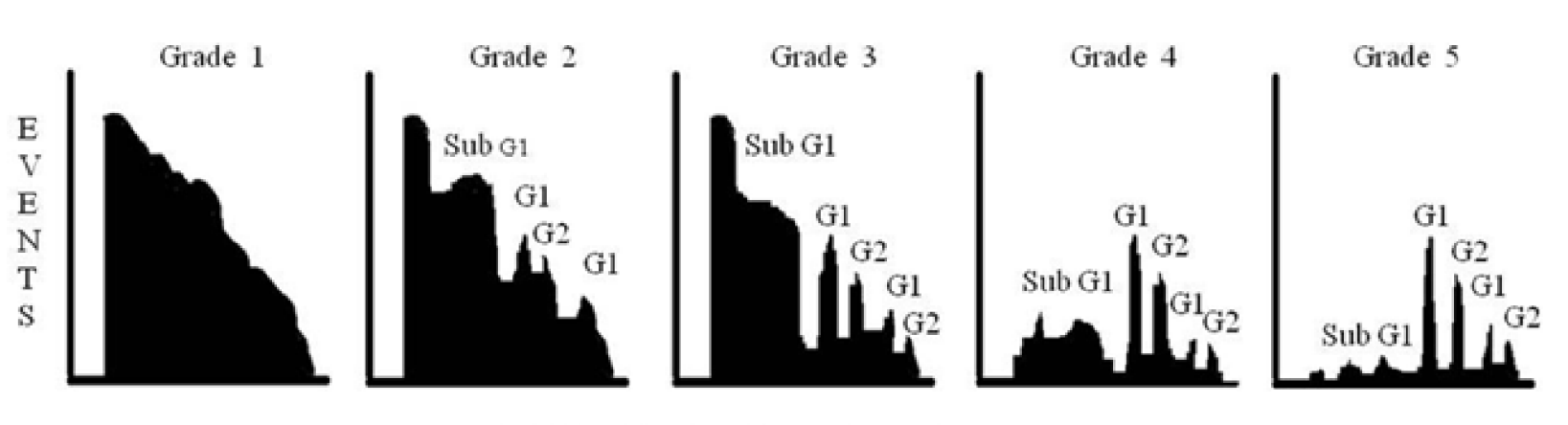

FLUORESCENCE INTENSITY

Figure 1 - Representation of the score system adopted for the evaluation of the histogram.

Grade 1: High amount of particles before the G1 peak (Sub G1) and non-occurrence of the G1 peaks of the sample and the standard; Grade 2: High amount of Sub G1 particles with initial occurrence of the G1 peaks of the sample and the standard; Grade 3: High amount of Sub G1 particles with occurrence of the G1 peaks of the sample and the standard more defined than in 2; Grade 4: Low amount of Sub G1 particles with occurrence of the G1 peaks of the sample and the standard more defined than in 3; Grade 5: Low amount of Sub G1 particles with occurrence of the G1 peaks of the sample and the standard with higher definition.

\section{RESULTS AND DISCUSSION}

Significant differences were observed for the general averages of the frequency and the coefficient of variation of the histogram in the estimates of the DNA content using different genotypes of Brachiaria spp, reference standards and nuclear isolation buffers (Table 3). Considering the best average of the frequency of the histogram and lowest $\mathrm{CV}$, the $\mathrm{MgSO} 4$ buffer and the reference standard $R$. sativus are indicated as the trustworthy estimate of the DNA content of the evaluated genotypes (Table 3). These results are in accordance with Doležel; Greilhuber and Suda et al. (2007) in which they affirm that the standards of reference and buffers used in the evaluations for flow cytometry intervene directly with the quality of the estimates of the DNA content.

The significance of the interactions of these sources of variation (standards and buffers) with genotypes was also observed (Table 4). In general, the buffer $\mathrm{MgSO}_{4}$ and Tris- $\mathrm{HCl}$ presented higher averages for score attributed to the histogram, independent of the reference standard used. The higher score of the histogram, the higher the definition of the G1 peaks of the sample and the standard, and the lower amount of sub G1 particles, which are generated due to the disruption of the nuclei. This indicates that these buffers were efficient in maintaining the nuclei integrity of the Brachiaria samples. One possible explanation for the better performance of the buffers Tris-HCL and $\mathrm{MgSO}_{4}$ could be the greater detergent concentration and higher $\mathrm{pH}$ buffer compared to Galbraith (Table 2). These variables, respectively, decreased aggregation of nuclei and debris and helped to stabilize the $\mathrm{pH}$ of the nuclear suspension at around 7.0, contributing to a better quality of histograms for Brachiaria species studied. This is according to Doležel, Greilhuber and Suda et al. (2007).

Table 3-General averages of the score and the coefficient of variation of the histogram in the estimates of the DNA content of the genotypes of Brachiaria obtained by flow cytometry.

\begin{tabular}{lcc}
\hline \multicolumn{1}{c}{ Standards } & Score* & CV \\
\hline R. sativus & $3.19 \mathrm{a}$ & $0.67 \mathrm{a}$ \\
S. lycopersicum & $2.83 \mathrm{~b}$ & $0.86 \mathrm{~b}$ \\
P. sativum & $2.69 \mathrm{~b}$ & $0.93 \mathrm{~b}$ \\
\hline \multicolumn{1}{c}{ Buffers } & & \\
\hline $\mathrm{MgSO}_{4}$ & $3.64 \mathrm{a}$ & $0.62 \mathrm{a}$ \\
Galbraith & $1.78 \mathrm{c}$ & $1.18 \mathrm{~b}$ \\
Tris-HCL & $3.31 \mathrm{~b}$ & $0.65 \mathrm{a}$ \\
\hline
\end{tabular}

*Means followed by same letter are not significantly different at $5 \%$ probability by Scott-Knott test. 
Histogram score contributes for reliability...

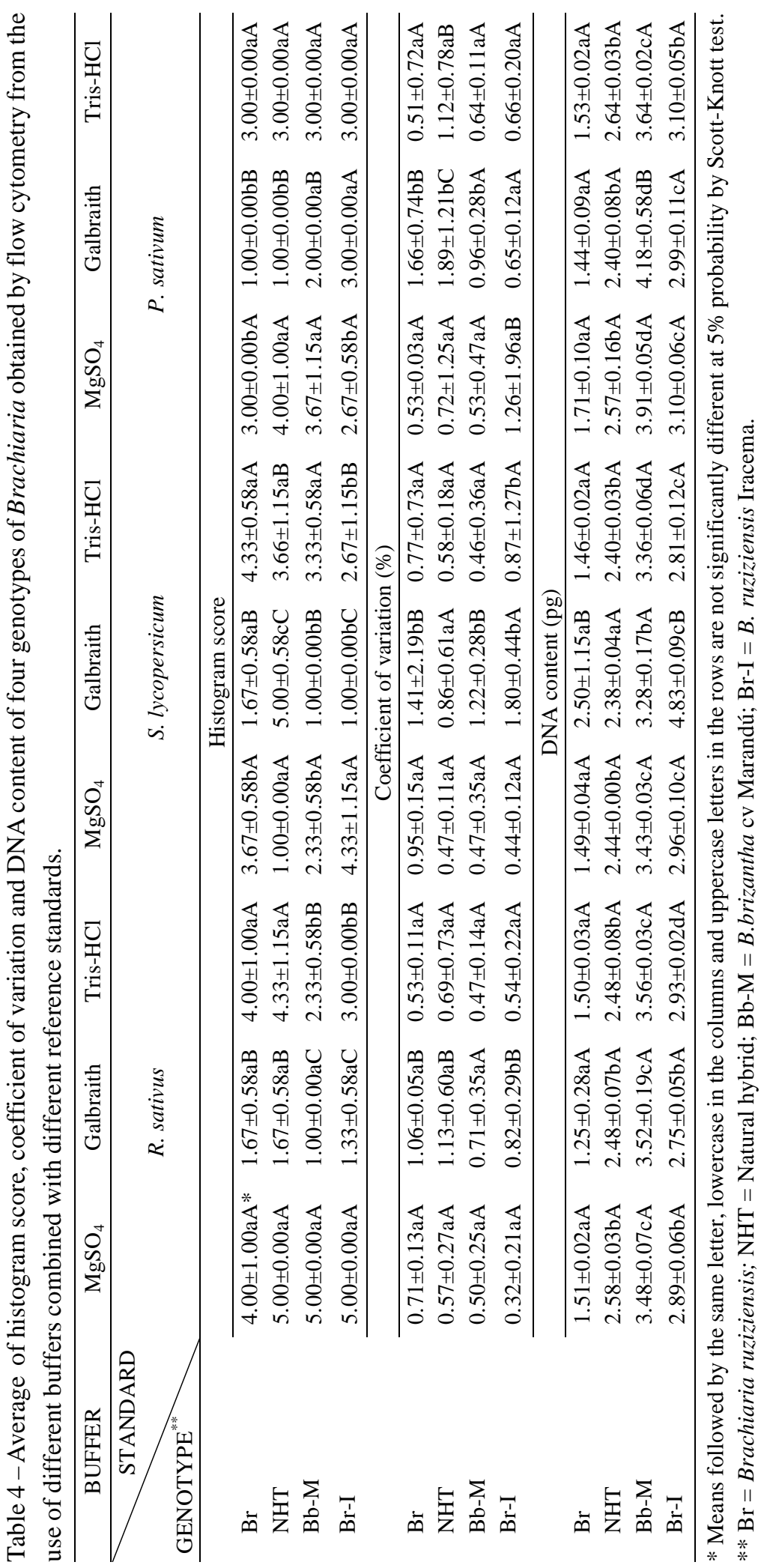

Ciênc. agrotec., Lavras, v. 36, n. 6, p. 599-607, nov./dez., 2012 
The treatments that had received the highest averages from the histogram presented, in general, low coefficients of variation, indicating association between these parameters (Tables 3 and 4). The correlation between these parameters was significant and negative $(-0.57)$. This fact was expected since the higher the frequency of the histogram, the lower the width of the G1 peaks, that is, the lower the CV of the G1 peak (Table 4 and Figure 1). It is important to mention that the histogram score also considers the amount of sub G1 particles (debris) that depend on the efficiency of the buffer in maintaining the integrity of the nuclei of the sample. In general, the frequency scale evaluates both the quality of the G1 peaks (CV) and the integrity of the nuclei.

Overall, the trustworthiness in the results of the DNA content estimates by flow cytometry is mentioned by the coefficients of variation attributed to the histograms generated from the readings. The $\mathrm{CV}$ can vary according, for example, to the buffers and standards used in the evaluations and to the vegetal species studied (DOLEŽEL et al., 1989; LOUREIRO et al., 2006). Evaluations that present CVs lower to 5\% have been considered trustworthy in literature and are difficult to be obtained for some plants (GALBRAITH et al., 1983;
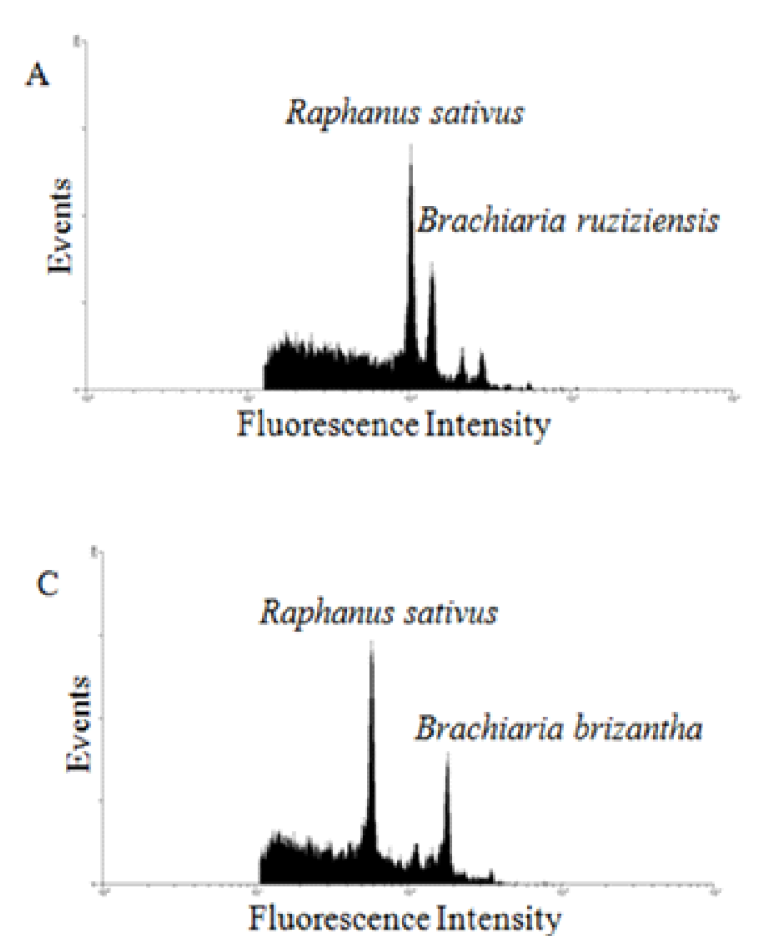

ULRICH;ULRICH, 1991; MARIE; BROWN, 1993; DOLEŽEL; BARTOS, 2005). In the conditions where the present work was carried out, $C V$ s considered low as was observed for $B$. brizantha cultivar Marandu $(0.96 \%)$ generated variations in the DNA content estimates when using the buffer Galbraith and Pisum sativum as reference standard (Table 4). When using this same buffer, we observed an error in the estimate of DNA content for the genotype of B. ruziziensis $(2.50 \pm 1.15$ pg) when compared with other estimated means of this genotype ranging from 1.25 to $1.71 \mathrm{pg}$ (Table 4). An important fact to be observed is that for these two situations, the histogram score was low (lesser or equal to 2), evidencing that this parameter can contribute for the definition of the reliability of the evaluations.

In the present study, the buffers $\mathrm{MgSO}_{4}$ and Tris$\mathrm{HCl}$, when used with standard $R$. sativus, were the only combinations capable of generating average values of $\mathrm{CV}$ equal to or below $0.71 \%$ for all the genotypes. The averages of the $\mathrm{CV}$ using the buffer $\mathrm{MgSO}_{4}$ varied from 0.32 to $0.71 \%$ and the scores attributed to the histogram were equal to or higher than 4 for the four genotypes studied, providing DNA content estimates of high trustworthiness (Table 4 and figures $2 \mathrm{a}-\mathrm{d}$ ).

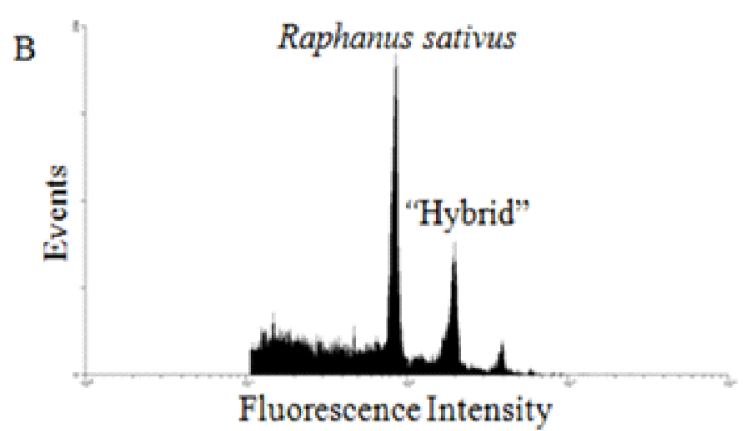

Figure 2 - Histograms of flow cytometry in the quantification of DNA content of Brachiaria obtained with the $\mathrm{MgSO}_{4}$ buffer. The first G1 peak is of Raphanus sativus which is the reference standard and the second peak refers to: (A) $B$. ruziziensis diploid, (B) natural triploid hybrid, (C) B. brizantha and (D) B. ruziziensis tetraploidized. 
However, in the evaluations of the natural hybrid using the $R$. sativus as the standard, it was observed histograms (Figure 2b) with overlapping of the $\mathrm{G} 2$ peaks of the standard with the G1 peaks of the sample, independent of the buffer used. The overlapping of peaks compromises the trustworthiness of the analyses, which is not recommended by Greilhuber; Temsch and Loureiro et al. (2007) and Price and Johnston (1996). Note that, although there was overlapping there was no error in the estimate of the DNA content (Table 4). The content averages of 2C DNA obtained using the MgSO4 buffer and the reference standard $R$. sativus for the Brachiaria species varied from $1.51 \mathrm{pg}$, for diploid B.ruziziensis, to $3.48 \mathrm{pg}$ for $B$. brizantha. The average estimates obtained for the Iracema genotype (tetraploidized B. ruziziensis) and for the natural hybrid were of 2,89 and $2.58 \mathrm{pg}$ of DNA, respectively. The value found for the natural hybrid is in accordance with that expected presuming that it was originated from the crossing between a diploid genotype (B. ruziziensis) and a tetraploid (B. brizantha), as the value obtained for the tetraploidized genotype is around double the estimate obtained for the diploid genotype (Table 4). Ishigaki et al. (2009) found average values in the 2C DNA content of $1.41 \mathrm{pg}$ for the diploid genotypes of $B$. ruziziensis and of $2.77 \mathrm{pg}$ for tetraploidizaded genotypes, using the Tris- $\mathrm{HCl}$ buffer and rice (Oryza sativa) as reference standard. These results demonstrate the variation obtained is a function of the use of different buffers and reference standards by different authors for the same species.

With this concern, Praça-Fontes et al. (2011) measured the DNA content of various species of plants and Drosophila melanogaster, which are routinely used as reference standard in flow cytometry. In this work, errors in the estimates of the DNA content were observed when a reference standard with a DNA content very different from the sample was used. Probably, this fact is due to the non linearity of the data. Moreover, not only the DNA content of the reference standard, but also the interaction of the reference standard $x$ sample can affect the trustworthiness of the estimates. Because of that, the authors suggest that some of the reference standards currently being used to estimate the DNA content, for example, R. sativus and G. max, must not be used for such objective, due to the interaction that these standards presented with the samples that were evaluated, generating estimates with low trustworthiness. However, it is important to mention that, in our research, $R$. sativus was the more appropriate reference standard, generating trustworthy estimates (Table 4).
Due to the fact that in literature there is variation in reports for the value of the CVs of the G1 peaks capable of generating trustworthy results (GALBRAITH et al., 1983; ULRICH; ULRICH, 1991), our work considers the use of a scale of values for the histogram in order to guarantee the trustworthiness of the results. In this scale, beyond the CV (definition of the G1 peak of the sample and the standard) it is also considered the amount of particles is sub G1 (debris). Thus, we recommend that the treatments that generate histograms with score equal to or higher than 4 should be considered as adequate values for the estimates of DNA content. According to this recommendation, the combination between reference standard $R$. sativus and the $\mathrm{MgSO}_{4}$ buffer presented greater trustworthiness in the estimates of the DNA content of the different genotypes of Brachiaria, in the conditions where these experiments had been carried out. This scoring system is similar to that used in the evaluation of characteristics such as disease severity and plant architecture (SCHOONHOVEN; PASTORCORRALES, 1987; MENDES; RAMALHO;ABREU, 2012).

This fact gives evidence to the necessity of carrying out pre-tests for the establishment of a precise methodology for each species in a laboratory/research group.

Thus, considering the attainment of histograms with low CVs, the quality of the histogram and the adequate choice of the reference standard, flow cytometry is a tool that can routinely be used for the characterization of a great number of genotypes in a short period of time.

The estimates of the DNA content allowed to distinguish B. ruziziensis (2x) from B. brizantha $(4 \mathrm{x})$, as well as the natural triploid hybrid and the tetraploidized genotype. This fact is of great importance for breeding programs of Brachiaria spp. once, in an efficient and fast way, it makes it possible to confirm the ploidy of materials derived from collections in pastures or improved populations in open field, where the contamination with pollen from tetraploid materials can take place, due to the difficulty of attaining isolated areas. Besides, it can also be useful in the verification of the efficiency of manipulation techniques of the ploidy level, mainly in works related to chromosomal duplication induction.

\section{CONCLUSIONS}

The combination of the $\mathrm{MgSO}_{4}$ buffer with the reference standard Raphanus sativus provides precise estimates of the DNA content of Brachiaria spp. making possible the separation of genotypes with different levels of ploidy in and among species. 
The association between the coefficients of variation and the scale of values attributed to the histogram generated from the readings of the samples in flow cytometry increases the trustworthiness of the evaluations carried out.

\section{ACKNOWLEDGMENTS}

The authors thank Dr Ana Luísa Sousa Azevedo and Dr Juliane Dornellas Nunes (Embrapa Gado de Leite) for collaboration in the analysis of flow cytometry and FAPEMIG, CNPq and Capes by financial support for the research.

\section{REFERENCES}

ARUMUGANATHAN, K.; EARLE, E. D. Estimation of nuclear DNA content of plants by flow cytometry. Plant Molecular Biology Reporter, New York, v.9, p.208-218, 1991.

CRUZ, C. D. Programa Genes: biometria. Viçosa, MG: UFV, v.1, p.382, 2006.

DOLEŽEL, J.; BINAROVA, P.; LUCRETTI, S. Analysis of nuclear DNA content in plant cells by flow cytometry. Biologia Plantarum, Praha, v.31, n.2, p.113120, 1989.

DOLEŽEL, J.; SGORBATI, S.; LUCRETTI, S. Comparison of three DNA fluorochromes for flow cytometric estimation of nuclear DNA content in plants. Physiologia Plantarum, Copenhagen, v.85, n.4, p.625-631, 1992.

DOLEŽEL, J.; BARTOS, J. Plant DNA flow cytometry and estimation of nuclear genome size. Annals of Botany, Oxford, v.95, p.99-110, 2005.

DOLEŽEL, J.; GREILHUBER, J.; SUDA, J. Flow cytometry with plant cells: analysis of genes, chromosomes and genomes. Wiley-VCH Verlag, Weinheim, p.454, 2007

FERREIRA, D.F. Sisvar ${ }^{\circledR}$ : Versão 4,6 (Build 61). Lavras, UFLA, 2003.

FERREIRA, D.F. SISVAR: A computer statistical analysis system. Ciência e Agrotecnologia, Lavras, v.35, n.6, p.1039-1042, nov./dez.2011.

GALBRAITH, D. W. et al. Rapid flow cytometric analysis of the cell-cycle in intact plant-tissues. Science, New York, v.220, p.1049-1051, 1983.
GREILHUBER, J. Intraspecifi c variation in genome size: A critical reassessment. Annals of Botany, Oxford, v.82, p.27-35, 1998.

GREILHUBER, J. et al. The origin, evolution and proposed stabilization of the terms 'genome size' and ' $\mathrm{C}$ value' to describe nuclear DNA contents. Annals of Botany, Oxford, v.95, p. 255-260, 2005.

GREILHUBER, J.; TEMSCH, E .; LOUREIRO, J. Nuclear DNA content measurement . In: DOLEŽEL J.;

GREILHUBER J.; SUDA J. editors. Flow cytometry with plant cells, Weinheim : Wiley-VCH; 2007.

ISHIGAKI, G. et al. Induction of tetraploid ruzigrass (Brachiaria ruziziensis) plants by colchicine treatment of in vitro multiple-shoot clumps and seedlings.

Japanese Society of Grassland Science. Nasushiobara, v.55, p.164-170, 2009.

ISHIGAKI, G. et al. Estimation of genome size in Brachiaria species. Japanese Society of Grassland Science. Nasushiobara, v.56, n.4, p.240-242, Dec. 2010.

JOHNSTON, J. et al. Reference standards for determination of DNA content of plant nuclei. American Journal of Botany, Columbus, v.86, p.609$613,1999$.

LOUREIRO, J. et al. Comparison of four nuclear isolaton buffer for plant DNA flow cytometry. Annals of Botany, Oxford, v.98, p.679-689, 2006.

\section{MACEDO, M. C. M. Aspectos edáficos relacionados com a produção de Brachiaria brizantha cultivar} Marandu. In: BARBOSA, R. A. (Ed.). Morte de pastos de braquiárias. Campo Grande: EMBRAPA Gado de Corte, 2006, p. 35-65.

MARIE, D.; BROWN, S. C. A cytometric exercise in plant DNA histograms, with $2 \mathrm{C}$ values for 70 species. Biology of the Cell, Paris, v.78, p. 41-51, 1993.

MENDES, M.P.; RAMALHO, M. A.P.; ABREU, A. F. Strategies in identifying individuals in a segregant population of common bean and implications of genotype $\mathrm{X}$ environment interaction in the success of selection. Genetic and Molecular Research, Ribeirão Preto, v.11, n.2, p.872-880, 2012. 
MILES, J. W. et al. Brachiariagrasses. In: Sollenberger, L. (ed) Warm-Season (C4) Grasses. ASA, CSSA, SSSA, Madison, p.745-760, 2004.

MICHAELSON, M.J.et al. Comparison of plant DNA contents determined by Feulgen microspectrophotometry and laser flow cytometry. American Journal of Botany, Columbus, v.78, p. 183188, 1991.

PEREIRA, A. V. et al. Selection of interspecific Brachiaria hybrids to intensify milk production on pastures. Crop Breeding and Applied Biotechnology, Viçosa, v.5, p.99-104, 2005.

PENTEADO, M. I. O. et al. Determinação de ploidia e avaliação da quantidade de DNA total em diferentes espécies do gênero Brachiaria. Campo Grande, EMBRAPA Gado de Corte. Boletim de Pesquisa, n.11, 2000, 32 p.

PINHEIRO, A. A. et al. Duplication of the chromosome number of diploid Brachiaria brizantha plants using colchicines. Plant Cell Reports, Berlin, v.19, p.274-278, 2000.

PRAÇA-FONTES, M. M. et al. Revisiting the DNA Cvalues of the genome size-standards used in plant flow cytometry to choose the "best primary standards". Plant Cell Reports, Berlin. v.30, p.11831191, 2011.

PRICE, H. E.; JOHNSTON, J. Analysis of plant DNA content by Feulgen microspectrophotometry and flow cytometry. In: Jauhar P P(Ed.). Methods of genome analysis in plants. Boca Raton: CRC, p.115-132, 1996.

RAYBURN, A.L. et al. Detection of intraspecific DNA content in Zea mays L by flow cytometry. Journal of Experimental Botany, Madison, v.40, p.1179-1183, 1989.

RAYBURN, A.L. et al. Documenting intraspecific genome size variation in soybean. Crop Science, Madison, v.44, p.261-264, 2004.

SCHOONHOVENA.; PASTOR-CORRALES M. Standard system for the evaluation of bean germoplasm. In: CIAT, C. (ed.). Centro Internacional de Agricultura Tropical. 1987. $53 \mathrm{p}$.

SCOTT, A., KNOTT, M. Cluster-analysis method for grouping means in analysis of variance. Biometrics, Washington, v.30, p.507-512, 1974.

SHAPIRO, H. M. Practical flow cytometry. Wiley, New York, 2003.

SUDA, J.; KYNCL, T.; FREIOVA, R. Nuclear DNA amounts in Macaronesian angiosperms. Annals of Botany, Oxford, v.92, p.153-164, 2003.

TROTTER, J. WINMDI ${ }^{\odot}$. Version 2.8. La Jolla: The Scripps Research Institute, 2000. Disponível em: <http:// facs.scripps.edu/software.html>. Acesso em: 10 maio 2010.

ULRICH, I.; ULRICH, W. High-resolution flow cytometry of nuclear DNA in higher plants. Protoplasma, New York, v.165, p.212-215, 1991. 